м-р Димитринка Јорданова

Пешевска

Факултетот за политички науки и психологија

Универзитет Американ Колеџ,

Скопје;

Проф. д-р Фимка Тозија

Институт за јавно здравје,

Медицински факултет,

Универзитет „Св. Кирил и

Методиј“, Скопје

\section{ЗЛОУПОТРЕБА И}

ЗАНЕМАРУВАЫЕ НА

ДЕЦАТА ВО РЕПУБЛИКА

МАКЕДОНИЈА, СЕГАШНА

СОСТОЈБА И ИДНИ

\section{НАСОКИ}

\section{Резиме}

Превенцијата и заштитата од насилство претставуваат најосновно право на секое дете. Сепак, насилството останува сериозна реалност за милиони деца, оставајќи долгорочни последици по животот на децата и нивниот развој. Основната цел на трудот е да се опише постоечката состојба со злоупотребата и занемарувањето на децата во Република Македонија, да се направи анализа на факторите на ризик, и да се отвори
MSc, Dimitrinka Jordanova

Peshevska

Faculty of Political Science and

Psychology,

University American College,

Skopje

Prof. Fimka Tozija MD, PhD

Institute of Public Health,

Faculty of Medicine,

Ss. Cyril and Methodius University,

Skopje

\section{ABUSE AND NEGLECT OF \\ CHILDREN IN MACEDONIA, \\ PRESENT SITUATION AND \\ FUTURE DIRECTIONS}

\section{Abstract}

The prevention and protection of children from violence is a fundamental right of every child. However, violence remains a severe reality for millions of children, having lifelong consequences on children's life span and development. The main objective of the paper is to describe the burden of child abuse and neglect, risk factors in Republic of Macedonia and discuss the need for national policy and legal framework reinforcement. 
дискусија за јакнење на имплементацијата на националните политики и законската регулатива.

Глобалните бази на податоци на Светската здравствена организација беа користени во презентирање на стапката на оптовареност од злоупотребата. Беше направен преглед на литературата и анализа на публикациите во врска со преваленција на различните видови на злоупотреба и занемарување кај децата во Република Македонија, како и анализа на можностите за имплементацијата на националните политики и законската регулатива.

Податоците на Светската здравствена организација (С3О) за регионот на Европа (за 53 земји членки) посочуваат дека 55 милиони деца $(29,1 \%)$ се жртви на емоционална злоупотреба, 44 милиони (22,9\%) на физичка злоупотреба, жртви на физичко занемарување се 31 милион (16,3\%), а, пак, 18 милиони деца $(9,6 \%)$ се жртви на сексуална злоупотреба. Според истражувањето во Македонија над една петтина (21\%) од испитаниците-адолесценти биле изложени на најразлични облици на физичка злоупотреба во текот на детството. Над 30\% од испитаниците биле изложени на некаков облик 96
The World Health Organization's Global Health Estimates data were used to describe the burden and mortality of child abuse and neglect, and literature review and analyses of previous reports were used to describe the prevalence of the different types of child abuse and neglect in Republic of Macedonia and discuss the options for national policy, as well as legal framework reinforcement.

The World Health Organization`s European Region of 53 states data, indicated that 55 million children (29.1\%) are victims of emotional abuse, 44 million (22.9\%) of physical abuse, victims of physical neglect are 31 million (16.3\%), and 18 million $(9.6 \%)$ children victims of sexual abuse. According to the research data, in Macedonia more than one fifth $(21 \%)$ of all students have been exposed to various forms of physical abuse during childhood. More than 30\% of the respondents-adolescents have been exposed to some form of psychological neglect; $11 \%$ to psychological abuse, and $13 \%$ to some kind of sexual abuse.

The problem of child abuse and neglect in Macedonia, in comparison with other countries from the South East European Region, has undergone impor- 
на психолошко занемарување; околу $11 \%$ биле изложени на психолошка злоупотреба, и речиси 13\% биле изложени на некој вид на сексуална злоупотреба.

Проблемот на злоупотреба и занемарување во Македонија, во споредба со земјите од Југоисточна Европа беше подложен на значајни пресвртници во насока на унапредување на превенцијата и заштитата на децата. Сепак, и понатаму постои можност од унапредување на националните стратегиски документи, законската регулатива и имплементација на програмите за превенција засновани на докази, бидејќи наодите од истражувањата сѐ уште говорат за висока преваленција на злоупотребата и занемарувањето на децата.

Клучни зборови: злоупотреба, занемарување, дете, оптовареност, превентивни мерки, национални политики

\section{ВОВЕД}

Превенцијата и заштитата на децата од злоупотреба и занемарување претставува едно од основните права на секое дете. За жал, сепак, насилството останува да биде сериозна tant milestones for improvement in prevention and protection of children from violence. However, there is an opportunity for improvement in reinforcing the national policies and legal framework, as well as implementing evidence based preventive programmes, since the findings are still confronting very high figures of prevalence of child abuse and neglect.

Key words: abuse, neglect, child, burden, preventive measures, national policies.

\section{INTRODUCTION}

The prevention and protection of children from violence is a fundamental right of every child. Unfortunately, violence remains a severe reality for millions of children around the world, leaving lifelong consequences on children`s lives and development (WHO, 1999). Violence impedes children's development, learning abilities and school achievement; it constrains relationships, contributes to low self-esteem, emotional distress and depression, leads to risk taking, self-harm and aggressive behaviours (UNICEF, 2010). 
реалност за милиони деца во светот, оставајќи долгорочни последици врз детскиот живот и нивниот развој (WHO, 1999). Насилството може да влијае негативно врз нарушување на детскиот развој, капацитетите за учење и училишните постигнувања, врз односите, ниската самодоверба, емоционално страдање и депресија, ризични и само-повредувачки однесувања, како и́ агресивни однесувања (UNICEF, 2010).

Децата кои доживеале злоупотреба и занемарување претставуваат една од најранливите категории на деца, како во светот, така и кај нас, во Македонија. Превенцијата и заштитата на децата од злоупотреба и занемарување се клучна одговорност на целиот систем. Тоа претставува сериозен, социјален, образовен и јавно-здравствен проблем, кој има сериозно влијание врз здравјето и благосостојбата на децата (Krug, Dahlberg, Mercy, Zwi, \& Lozano, 2002). Конвенција за правата на детето (КПД) 1989 е еден од највлијателните меѓународни инструменти во заштитата и превенцијата на децата од насилство, поаѓајќи од најдобриот интерес на детето. КПД придонесе поголем број на земји да пристапат кон примена на различни мерки за унапредување 98
Abused and neglected children are one of the most vulnerable groups of children globally, as well as in Macedonia. Prevention and protection of abused and neglected children are the key responsibility of the entire system. Child abuse and neglect (child maltreatment) is a serious, social, educational and public health problem that has grave impact on health and well-being of children (Krug, Dahlberg, Mercy, Zwi, \& Lozano, 2002). The United Nations Convention on the Rights of the Child, 1989 has been an influential tool for protection and prevention of children from violence, supporting the best interest of the child. This has led to a number of countries implementing various measures towards protecting children from violence, including prohibiting the use of physical punishment on children, especially article 19 (UN CRC, 1989).

The promotion of the World report on violence and health 2002, of the World Health Organization (WHO) has brought a renewed attention for health and social professionals, as well as policy makers on the importance of the child abuse and neglect (child maltreatment). Child maltreatment is resulting in harm to the child's health, survival, devel- 
и заштита на децата од насилство, вклучувајќи ја и забраната за користење на физичкото казнување на децата, особено членот 19 (UN CRC, 1989).

Промоцијата на Светскиот извештај за насилство и здравје на Светската здравствена организација (C3O) во 2002 година повторно го насочи вниманието на здравствените, социјалните професионалци и креаторите на националните политики за важноста на злоупотребата и занемарувањето на децата. Злоупотребата и занемарувањето влијаат врз здравјето, опстанокот, развојот и достоинството на детето (Krug et al., 2002). Co Peзолуцијата 56.24 на Собранието на Светската здравствена организација насилството се става на меѓународната агенда, нагласувајќи ја важноста од справување со овој сериозен јавно-здравствен проблем (WHO, 2003). Дополнително, насилството доведува до сериозни економски последици, намалувајќи ги човечките потенцијали, загрозувајќи го социјалниот капитал (UNICEF, 2010).

Во 2005 година, со Резолуцијата на Регионалниот комитет EUR/RC55/10 за повреди во европскиот регион на С3О, висок приоритет и́ се даде на акцијата за превенција на насилството и opment or dignity (Krug et al., 2002). The World Health Assembly resolution 56.24 put violence on the international agenda, highlighting the importance in facing this major public health problem (WHO, 2003). Additionally, violence conveys serious economic impact for society, reducing human capacity and compromising social capital (UNICEF, 2010).

Later, the Regional Committee resolution, EUR/RC55/10 on Injuries in the WHO European Region, gave high priority to the prevention of violence and unintentional injury to act upon (WHO, 2005). The United Nations Secretary General's World report on violence against children, 2006 suggests that many governments have commenced all-encompassing efforts in the field of legal reform and policy consideration to address violence against children (Pinheiro, 2006). The report highlights the need of governments to protect children from violence, conveying the message that "no violence against children is justifiable, and all forms of violence are preventable". The message needs accurate translation into action: end violence against children, whether accepted by 
ненамерните повреди (WHO, 2005). Светскиот извештај за студијата на Генералниот секретар на Обединетите Нации за насилството врз децата, исто така информира за тоа дека многу влади започнаа сеопфатни напори во областа на законските реформи и унапредувањето на политиките за справување со насилството врз децата (Pinheiro, 2006). Во извештајот се нагласува потребата владите да ги заштитат децата од насилство, пренесувајќи ја пораката дека „ниедно насилство врз децата не е оправдано и дека сите форми на насилство можат да се спречат“. Потребно е пораката да се преточи во акција - да се сопре насилството врз децата, без разлика дали е прикажано под маската „традиција“ или прикриено како „воспитување“" (Pinheiro, 2006).

Европскиот извештај запревенција на злоупотребата и занемарувањето на децата, 2013 година на креаторите на националните стратегии им ги приближи превентивните практики засновани на докази за справување со злоупотреба и занемарување на децата (Sethi, Bellis, Hughes, Gilbert, Mitis, \& Galea, 2013). Резолуцијата EU/RC64/R6 на Регионалниот комитет на СЗО „Инвестирање во децата: Европска стратегија за здравјето на 100 'tradition' or veiled as 'discipline' (Pinheiro, 2006).

The European report on preventing child maltreatment, 2013 provides policy-makers preventive evidence based practices to tackle child abuse and neglect (Sethi, Bellis, Hughes, Gilbert, Mitis, \& Galea, 2013). The WHO Regional Committee resolution, EU/RC64/ R6: "Investing in children: the European child and adolescent health strategy 2015-2020" and "Investing in children: the European child maltreatment prevention action plan 2015-2020" put emphasis to improve the health and well-being of children and reduce the burden of maltreatment and other adverse childhood experiences (ACE), (WHO, 2014a).

Modern public and scientific attention to the issue of child maltreatment is often attached to Henry Kempe's 1962 article in the Journal of the American Medical Association on the "battered child syndrome" (Kempe, Silverman, Steele, Droegemueller, \& Silver, 1962) examined in the clinical case studies to explain maltreatment patterns. Kempe and collaborators found that overloaded parents/caregivers or depressed single parents were using extreme forms of 
децата и адолесцентите 2015-2020 година“ и „Инвестирање во децата: Европски акционен план за превенција на злоупотреба и занемарување на децата 2015-2020 година“" ставија акцент врз унапредување на здравјето и благосостојбата на децата и намалување на стапката на оптовареност од злоупотреба, занемарување и други негативни искуства од детството (WHO, 2014).

За прв пат во јавноста, како и́ во научната јавност поимот на злоупотреба и занемарување на децата се поврзува со името на истражувачот Хенри Кемп и неговите соработници, (Henry Kempe) и трудот во Списанието на Американското медицинско здружение со терминот „синдром на тепани деца“" или ,,battered child syndrome" (Kempe, Silverman, Steele, Droegemueller, \& Silver, 1962). Групата на истражувачи спроведуваат клиничка студија со цел да се објаснат моделите на злоупотреба на децата. Резултатите покажале дека родителите/згрижувачите кои биле премногу ангажирани со обврски во поголема мера користеле екстремни форми на физичко казнување на децата, не успевајќи на своите деца да им ги обезбедат основните емоционални и физички потреби. Понатаму, пе- corporal punishment failing to provide for their children's basic emotional and physical needs. The 1980s represented a period of significant expansion in public awareness of child maltreatment, research on its underlying causes and consequences. In that period also are developed and disseminated large number of clinical trials and preventive intervention and programs. By the 1990s, emphasis was placed on establishing a strong foundation of support for every parent and child, especially by establishing home visitation programmes, available when a child is born or a woman is pregnant. The beginning of the new millennium was marked by placing more emphasis on prevention and implementing evidence based interventions.

Child abuse is considered as intentional use of force in the context of a relationship of trust or power that can harm child's health, survival, development or dignity. Child neglect is considered as failure to provide for a child's basic physical, emotional, or educational needs or to protect a child from harm or potential harm (Krug et al., 2002).

The World report on violence and health 2002, defines child abuse and neglect (child maltreatment) as: 
риодот на 80-те години претставува период на значајна експанзија на јавната свест за злоупотребата и занемарувањето на децата и истражувања за причините и последиците од злоупотребата и занемарувањето. Во тој период, исто така, се спроведуваат голем број на клинички студии и превентивни интервенции и програми. До 90-те години на 20-от век, акцентот беше ставен на воспоставувањето на силна поддршка на секој родител и секое дете, особено преку воспоставување на патронажните служби, достапни за секое новородено дете, или, пак, во периодот на забременувањето на жената. На почетокот на милениумот поголемо внимание се обрна на превенцијата и спроведувањето на интервенциите засновани на докази.

Злоупотребата на децата подразбира намерна употреба на сила од позиција на моќ при односи на доверба, која може да предизвика штета по здравјето на детето, опстанокот, развојот или дигнитетот. Занемарувањето, пак, подразбира неуспех да се задоволат основните физички, емоционални, образовни и/или здравствени потреби на детето и/или неможност да се заштити детето од потенцијална повреда или штета (Krug et al., 2002). Во рамки на Светскиот извештај за 102 "all forms of physical and/or emotional or sexual abuse, deprivation and neglect of children or commercial or other exploitation resulting in harm to the child's health, survival, development or dignity in the context of a relationship of responsibility, trust or power" (Krug et al., 2002, p.59). Four types of child maltreatment are distinguished: physical, sexual, and emotional (psychological) abuse and neglect (WHO, 1999).

In addition, violence against children has been defined as: "all forms of physical or mental violence, injury and abuse, neglect or negligent treatment, maltreatment or exploitation, including sexual abuse against young people under 18 years" (Gray, Jordanova Pesevska, Sethi, González, \& Yon, 2016). It includes much broader concept than child maltreatment; for instance, it is not necessary for it to occur in the context of a relationship of responsibility, trust or power, but can be perpetrated by anyone - peers, strangers or any individual or group (Pinheiro, 2006).

A growing body of research is now showing that the use of corporal punishment is linked to a range of negative consequences on children, including in- 
насилство и здравје, 2002 година злоупотребата и занемарувањето на децата се дефинира како:

„која било форма на физичко и/ или емоционално злоупотребување, сексуална злоупотреба, занемарување или занемарувачки третман или комерцијална или друг вид експлоатација, што потенцијално или реално предизвикува закана или штета по здравјето на детето, опстанокот, развојот или дигнитетот, во контекст на меѓусебен однос на одговорност, доверба или моќ“ (Krug et al., 2002, стр.59). Се разликуваат четири видови на злоупотреба и занемарување на децата и тоа: физичка, сексуална, психолошка (емоционална) злоупотреба и занемарување (WHO, 1999).

Од друга страна, насилството врз децата се дефинира како: „сите форми на физичко или психолошко насилство, повреда или злоупотреба, занемарување или занемарувачки третман, злоупотреба или експлоатација, вклучувајќк ја и сексуална злоупотреба на деца до 18 години возраст“ (Gray, Jordanova Pesevska, Sethi, González, \& Yon, 2016). Оваа дефиниција вклучува поширок концепт од претходната, бидејќи се проширува, не само на контекстот на меѓусебен однос на одговорност, доверба или creased mental-health problems, problems at the establishing relationship and/or increased aggression in children (Durrant et al, 2012; Ferguson, 2013; Gershoff, 2010; Gershoff, 2013). Corporal punishment is defined as "the use of physical force with the intention of causing a child to experience pain, but not injury, for the purpose of correcting or controlling the child's behaviour" (Donnelly \& Straus, 2005, p. 3). A review of the literature has also shown that spanking is ineffective way of child disciplining and is becoming discouraged by relevant international community and organizations (Gershoff, 2013).

\section{METHOD}

The analysis relies on secondary information attained through a computer-based search provided by various projects, organizations and agency websites, which reflect latest policies, laws, programmes, services, measures on child abuse and neglect. The following data basis have been searched: Cochraine Controlled Trial Register, MEDLINE, EBSCO, Social Science Search, and PubMed, WHO, UNICEF, 
моќ, туку злоупотреба од кое било лице - врсници, странци, или која било индивидуа или група (Pinheiro, 2006).

Денес поголем број истражувања покажуваат дека употребата на физичкото (телесното) казнување на детето, исто така, е поврзано со голем број на негативни последици како што се: проблеми со менталното здравје, проблеми на младите во воспоставување на релациите со другите и зголемување на агресивното однесување (Durrant et al, 2012; Ferguson, 2013; Gershoff, 2010; Gershoff, 2013). Телесното казнување е дефинирано како „употреба на физичка сила со намера да се предизвика болка кај детето, но не и́ повреда, со цел да се коригира или контролира однесувањето на детето“ (Donnelly \& Straus, 2005, p. 3). Прегледот на литературата, пак, покажува дека тепањето претставува неефикасен начин на воспитување на децата и започна да биде критикуван од страна на релевантните меѓународни заедници и организации (Gershoff, 2013).

\section{Метод}

Анализата има секундарен карактер и се потпира на информациите добиени со компјутерско пребарување на веб 104
UNESCO, and Council of Europe and ministries of Macedonia and other websites. Terms searched both in Macedonian and English language were: "child maltreatment", "child abuse and neglect", "child prevention", "child protection", "domestic violence", "children rights", and "child protection organizations". The documents selected, according to the above mentioned search criteria in these areas, have been included in the analysis. The criterion regarding the time frame includes the latest possible available documents.

Risks factors and the extent of child abuse and neglect in Republic of Macedonia.

The ecological model of understanding human development was primarily proposed by Bronfenbrenner (1993) and later adopted by Belsky (1980) when explaining determinants of parenting and child maltreatment. In 2002 World Health Organization in line with the Bronfenbrenner's model has proposed the ecological framework of understanding violence. According to the WHO's ecological model, violence is a considered as consequence of various factors organized into a framework of four principal systems: 1) the child, 2) 
страниците на најразлични проекти, организации и агенции, а коишто ги содржат најновите политики, закони, програми, служби, мерки за превенција на злоупотреба и занемарување. Беа пребарани следниве бази на податоци: Cochraine Controlled Trial Register, MEDLINE, EBSCO, Social Science Search, PubMed, СЗО, УНИЦЕФ, УНЕСКО и Советот на Европа, како и тие на веб страниците на сите министерства во Република Македонија. Следниве термини беа пребарувани, како на македонски, така и на англиски јазик: „злоупотреба и занемарување на децата“, „превенција кај децата“, „заштита на децата“, „семејно насилство“, „правата на децата“, и „организации за заштита на децата“. Во анализата беа вклучени документи кои беа избрани согласно со погоре споменатите критериуми за пребарување на овие области. Критериумот што се однесува на временската рамка ги вклучува најновите достапни документи.

Ризик фактори и постоечка состојба со злоупотребата и занемарувањето на децата во Република Македонија

Еколошкиот модел на разбирање на екологијата на човековиот развој, најпрво беше предложен од страна на Бронфенбренер (Bronfenbrenner, 1993) за да подоцна биде адаптиран од страна the family, 3) the community, and 4) the society.

These factors are influencing on different levels: individual (biological and personal characteristics, age, sex, factors of personal history), relationships (individual's relationships with family members, relatives, friends and others), community (socio-economic disadvantage, poor social capital, availability of alcohol and drugs, neighbourhoods, workplaces, schools and other social networks) and society (social norms that support acceptance of violence, economic inequalities, poverty, societal conflicts, week legislation or policy), (Butchart, Harvey, Mian, \& Furniss, 2006).

\section{Figure1. Ecological model of un-} derstanding violence (adopted from Krug et al., 2002)

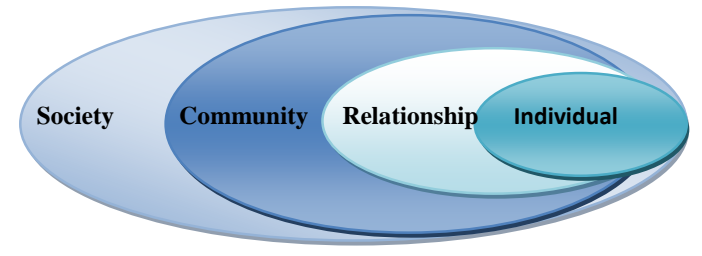

Exposure to different types of child abuse and neglect and other adverse childhood experiences (ACEs) in the household dysfunctions such as: living 
на Белски (Belsky, 1980) кој зборува за детерминантите на родителството при злоупотреба и занемарување на децата. Во 2002 година СЗО се надоврзува на моделот на Бронфенбренер и ја поставува еколошката концептуална рамка за разбирање на насилството. Според еколошкиот модел на СЗО насилството се јавува како резултат на влијание на повеќе фактори едновремено, групирани во рамки на следниве 4 групи на: 1) индивидуа/дете, 2) семејство/релации, 3) заедница, и 4) општество.

Повеќеслојниот модел на СЗО за разбирање на насилството најдобро може да се разбере по пат на анализа на сложената интеракција на овие разновидните фактори на различни нивоа на влијание. Овие фактори (слика 1.) имаат влијание на повеќе нивоа: на ниво на индивидуа (биолошките и личните карактеристики, возраст, пол, фактори од личното минато), на ниво на односи/релации (односот на поединецот со членовите на семејството, роднините, пријателите и други), на ниво на заедницата (социо-економските недостатоци, слаб општествен капитал, достапност на алкохол и дроги, соседство, работни места, училишта и други општествени мрежи) и на ниво на општеството (општествени норми кои одат во прилог на прифаќање на 106 with a family member who is an alcoholic, drug addict, mentally ill, or who has been imprisoned, may also affect children and future life outcomes (Butchart et al., 2006; Sethi et al., 2013).

The World Health Organization data indicated that 55 million children (29.1\%) are victims of emotional abuse, 44 million $(22.9 \%)$ of physical abuse, victims of physical neglect are 31 million (16.3\%), and 18 million (9.6\%) children victims of sexual abuse in Europe. Additionally, reported data on 34,000 homicidal deaths among youngsters fewer than 15 years of age each year, with $20 \%$ of females (Sethi, et al., 2013; WHO, 2013; Sethi, \& Jordanova Peshevska, 2014).

The data on child maltreatment in the country are mainly gathered from the studies conducted in the country or in the region. One of the studies implemented, is the adverse childhood experiences (ACEs) study in Macedonia, conducted on a representative sample of 1277 high school and university students, aged 18 years and over (Raleva, Jordanova Peshevska, \& Sethi, 2013). 
насилството, економска нееднаквост, сиромаштија, општествени конфликти, слабо законодавство или политики), (Butchart, Harvey, Mian, \& Furniss, 2006).

Слика 1. Еколошки модел за разбирање на насилството (превземено од Krug et al., 2002)

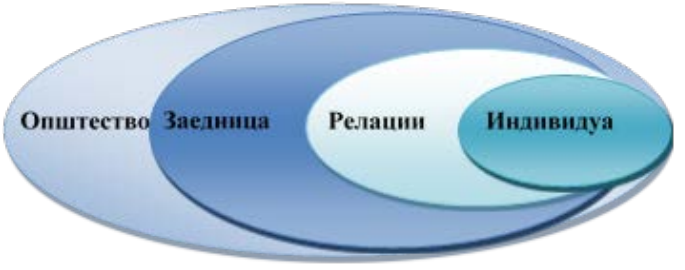

Изложеноста на различни видови на злоупотреба и занемарување и други негативни искуства во детството во дисфункционалните семејства (живеење со член од семејството кој употребува алкохол, дрога, член од семејството кој бил во затвор, или ментално болен), исто така може да имаат влијание врз децата и нивниот понатамошен живот (Butchart et al., 2006; Sethi et al., 2013).

Податоците на Светската здравствена организација посочуваат дека 55 милиони деца $(29,1 \%)$ се жртви на емоционална злоупотреба, 44 милиони $(22,9 \%)$ на физичка злоупотреба, жртви на физичко занемарување се 31 милион (16,3\%), а пак 18 милиони деца (9,6\%) се жртви на сексуална злоупотреба во Европа. Покрај тоа, пријавени
Overview 1. Adverse childhood experiences study among university students in Macedonia

\begin{tabular}{l|l}
\hline $\begin{array}{l}\text { ACE (during the first } 18 \text { years } \\
\text { of life) }\end{array}$ & Total (\%) \\
\hline Physical abuse & 21.1 \\
\hline Psychological abuse & 10.8 \\
\hline Sexual abuse & 12.9 \\
\hline Physical neglect & 20 \\
\hline Psychological neglect & 30.6 \\
\hline $\begin{array}{l}\text { Physical (corporal) punish- } \\
\text { ment }\end{array}$ & 72.4 \\
\hline
\end{tabular}

Source: Raleva, Jordanova Peshevska \& Sethi, 2013.

According to the data presented in Overview 1., more than one fifth (21\%) of all university and high school students have been exposed to various forms of physical abuse during childhood. More than 30\% of the respondents have been exposed to some form of psychological neglect; around 11\% of the respondents have been exposed to psychological abuse, and nearly $13 \%$ of the respondents have been exposed to some kind of sexual abuse. Nearly 65\% of the respondents have been exposed to some kind of abuse and neglect, with $35 \%$ of the respondents exposed to multiple kinds of adverse experiences as a result of abuse and neglect during childhood (Raleva et al., 2013). 
ce 34.000 случаи на убиство на лица помлади од 15 години, при што $20 \%$ се од женски пол (Sethi, et al., 2013; WHO, 2013; Sethi \& Jordanova Peshevska, 2014).

Податоците за злоупотребата и занемарување на децата во земјата во најголем дел произлегуваат од студии спроведени во земјава и регионот. Една од позначајните студии е секако студијата за негативните искуства во детството (НИД) во Македонија, спроведена на репрезентативен примерок од 1.277 ученици и студенти на возраст од 18 или повеќе години (Raleva, Jordanova Peshevska \& Sethi, 2013).

Преглед 1. Негативни искуства во детството

\begin{tabular}{l|l}
\hline $\begin{array}{l}\text { Негативните искуства во } \\
\text { детството (во текот на } \\
\text { првите } 18 \text { години живот) }\end{array}$ & Вкупно (\%) \\
\hline Физичка злоупотреба & $\mathbf{2 1 , 1}$ \\
\hline Психолошка злоупотреба & $\mathbf{1 0 , 8}$ \\
\hline Сексуална злоупотреба & $\mathbf{1 2 , 9}$ \\
\hline Физичко занемарување & $\mathbf{2 0}$ \\
\hline Психолошко занемарување & $\mathbf{3 0 , 6}$ \\
\hline $\begin{array}{l}\text { Физичко (телесно) } \\
\text { казнување }\end{array}$ & $\mathbf{7 2 , 4}$ \\
\hline
\end{tabular}

Извор: Raleva, Jordanova Peshevska \& Sethi, 2013.

Како што е прикажано во преглед 1 , над една петтина (21\%) од испитаниците биле изложени на најразлични облици на физичка злоупотреба во текот на детството. Над $30 \%$ од испи108
In the Global School-based health survey data overall, $31.3 \%$ of students said they had been seriously injured one or more times during the past 12 months. Male students $(37.3 \%)$ were seriously injured more often than female students (24.9\%), (Tozija, Gjorgjev, Kjosevska, $\&$ Kendrovski, 2008). Overall, 10.0\% of students were bullied on one and more days during the past 30 days. The share was the same for male and female students (Tozija et al., 2008).

The findings from the UNICEF Multiple Indicator Cluster Survey showed big discrepancy in marriage before age of 15 among women age 15-19 years where in Macedonians is $1.4 \%$ and in Roma settlements is $11.9 \%$. The attitudes towards domestic violence of women age 15-49 years is nearly twice higher in Roma settlements. Health risk behaviors such as tobacco use and alcohol use are also present. Tobacco use among women age 15-49 years is very high in Macedonian (30\%) and even higher in Roma settlements (42\%). The use of alcohol before the age 15 among women is higher in Macedonians $(28.5 \%)$ compared to Roma women with $11.2 \%$ (Ministry of Health, Ministry of Education and Science, and Min- 
таниците биле изложени на некаков облик на психолошко занемарување; околу 11\% биле изложени на психолошка злоупотреба, и речиси 13\% биле изложени на некој вид на сексуална злоупотреба. Речиси 65\% од испитаниците биле изложени на некој вид на злоупотреба и занемарување, при што $35 \%$ од испитаниците биле изложени на повеќекратни видови на негативни искуства како последица на злоупотреба и занемарување во детството (Raleva et al., 2013).

Според податоците од Глобалното истражување на здравјето на учениците во училиштата, околу $31,3 \%$ од учениците изјавиле дека биле сериозно повредени еднаш или повеќе пати во изминатите 12 месеци. Машките ученици $(37,3 \%)$ биле почесто сериозно повредувани од ученичките (24,9\%), (Tozija, Gjorgjev, Kjosevska, \& Kendrovski, 2008). Севкупно, 10,0\% од учениците биле жртви на булинг, еднаш или повеќе пати во текот на 30 дена. Подеднакво е застапен и кај учениците и ученичките (Tozija, 2008).

Наодите од Мултииндикаторското кластерско истражување, 2011 година на УНИЦЕФ, покажуваат големи разлики во однос на стапувањето во брак пред возраст од 15 години помеѓу македонската (1.4\%) и ромската популација (11.9\%) на адолесцентки. Степенот на прифаќање на семејно насил- istry of Labor and Social Policy, 2012a).

Corporal punishment has also been shown to be the most prevalent and one of the most common ways of child disciplining, where $72 \%$ of the respondents have had such experience during childhood from their parents/caregivers. (Raleva et al., 2013; Ministry of Health, Ministry of Education and Science, and Ministry of Labor and Social Policy, 2012). The high rate of $72 \%$ of violent disciplining of children have been also confirmed in the UNICEF Multiple Indicator Cluster Survey with nearly $69,3 \%$ of the parents using corporal punishment in Macedonian children and even higher in Roma settlements with $82 \%$ (Ministry of Health, Ministry of Education and Science, and Ministry of Labor and Social Policy, 2012a).

Studies of adverse childhood experiences among students, besides in Macedonia, have also been done in several other South-East European countries as presented in Table 1., such as: Albania, Montenegro and Serbia (Qirjako, Burazeri, Sethi, \& Miho, 2013; Paunovic, Markovic, Vojvodic, Neskovic, Sethi \& Grbic, 2015; Raleva et al., 2013, WHO, 2014b).The comparative data from the several South-East European countries 
ство кај жените на возраст од 15-49 години е речиси два пати повисок кај ромската популација. Присутни се и однесувања кои преставуваат здравствен ризик, како што е употребата на тутун и употребата на алкохол. Употребата на тутун кај жените на возраст од 15-49 години е многу висока во македонската (30\%) и уште повисока кај ромската популација (42\%), додека пак употребата на алкохол кај жените пред да наполнат 15 години е повисока кај Македонките $(28,5 \%)$ во однос на Ромките (11,2\%), (Министерство за здравство, Министерство за образование и наука, Министерство за труд и социјална политика на Република Македонија, 2012a).

Телесното казнување според податоците од истражувањата претставува најчест начин на дисциплинирање на децата, при што $72 \%$ од испитаниците пријавиле таков вид на искуство во своето детство, доживеано од страна на нивните родители/згрижувачи (Raleva et al., 2013). Високата стапка од $72 \%$ на насилно дисциплинирање на децата, којашто беше посочена во истражувањето, исто така, беше потврдена и во истражувањето на УНИЦЕФ, при што стапката изнесуваше $69,3 \%$ во македонската, а многу повеќе во ромската популација 82\% (Министерство за здравство, Министерство за образование и наука, Ми110 are presenting the highest prevalent rates for both physical neglect $(20,9 \%)$ and emotional neglect $(30,6 \%)$ in Macedonia comparison the other countries, followed by the Montenegro with 27\% emotional neglect, and Serbia with $15,5 \%$. Physical abuse with $41,5 \%$ was the most prevailing in Albania, followed by Montenegro (24,3\%) and Macedonia with $21 \%$. Sexual abuse was prevalent in Macedonia in comparison with other countries with 14,1\% (Qirjako et al., 2013; Paunovic, 2013; Raleva et al., 2013; WHO, 2014b). 
нистерство за труд и социјална политика на Република Македонија, 2012a).

Покрај Македонија, студии за негативните искуства во детството, беа направени и во други земји од Југоисточна Европа, презентирани во табела 1. Tоа се: Албанија, Црна Гора и Србија (Qirjako, Burazeri, Sethi, \& Miho, 2013; Paunovic, Markovic, Vojvodic, Neskovic, Sethi \& Grbic, 2015; Raleva et al., 2013, WHO, 2014a). Компаративните податоци од земјите на Југоисточна Европа покажуваат висока преваленција за физичкото $(20,9 \%)$ и емоционалното $(30,6 \%)$ занемарување на децата во Македонија во споредба со другите земји, потоа следи Црна Гора со 27\% и Србија со 15,5\%. Физичката злоупотреба со 41, 5\% е најзастапена во Албанија, потоа во Црна Гора $(24,3 \%)$ и во Македонија со преваленција од $21 \%$. Сексуалната злоупотреба е најзастапена во Македонија во споредба со другите земји од регионот и Европа со 12,9\%. (Qirjako et al., 2013; Paunovic, 2013; Raleva et al., 2013; WHO, 2014a).

Табела 1. Резултати од истражувањата на негативните искуства во детството кај студенти во неколку земји од Југоисточна Европа

\begin{tabular}{|c|c|c|c|c|}
\hline $\begin{array}{l}\text { Негативни искуства } \\
\text { во детството (до } 18 \\
\text { години) }\end{array}$ & $\begin{array}{c}\text { Албанија } \\
\text { Вкупно (\%) } \\
(\mathbf{N = 1 4 3 7 )}\end{array}$ & $\begin{array}{c}\text { Македонија } \\
\text { Вкупно (\%) } \\
(\mathbf{N}=\mathbf{1 2 7 7})\end{array}$ & $\begin{array}{c}\text { Црна Гора } \\
\text { Вкупно (\%) } \\
(\mathbf{N = 1 6 0 0 )}\end{array}$ & $\begin{array}{c}\text { Србија } \\
\text { Вкупно (\%) } \\
(\mathbf{N}=\mathbf{2 3 8 1})\end{array}$ \\
\hline Физичка злоупотреба & 41,5 & 21 & 24,3 & 11,4 \\
\hline $\begin{array}{l}\text { Психолошка } \\
\text { злоупотреба }\end{array}$ & 51,1 & 10,8 & 30,4 & 17,8 \\
\hline Сексуална злоупотреба & 6 & 12,9 & 3,9 & 5 \\
\hline Физичко занемарување & 6,5 & 20,9 & 18,8 & 9,5 \\
\hline $\begin{array}{l}\text { Психолошко } \\
\text { занемарување }\end{array}$ & 11,2 & 30,6 & 27 & 15,5 \\
\hline \multicolumn{5}{|l|}{$\begin{array}{l}\text { Семејна } \\
\text { дисфункционалност }\end{array}$} \\
\hline $\begin{array}{l}\text { Родител злоупотребува } \\
\text { дрога }\end{array}$ & 1,6 & 3,6 & 3,6 & NA \\
\hline $\begin{array}{l}\text { Родител злоупотребува } \\
\text { алкохол }\end{array}$ & 20,5 & 10,7 & 11,9 & 9,1 \\
\hline $\begin{array}{l}\text { Ментална болест во } \\
\text { семејство }\end{array}$ & 6,8 & 6,9 & 6,1 & 6,6 \\
\hline $\begin{array}{l}\text { Мајка третирана } \\
\text { насилно во семејството }\end{array}$ & 30,1 & 10 & 24 & 18,7 \\
\hline $\begin{array}{l}\text { Член на семејство во } \\
\text { затвор }\end{array}$ & 3,8 & 5 & 7,8 & NA \\
\hline $\begin{array}{l}\text { Разделени/разведени } \\
\text { родители }\end{array}$ & 6,6 & 3,8 & 10,6 & 12 \\
\hline
\end{tabular}

Извор: Qirjako, Burazeri, Sethi, \& Miho, 2013; Paunovic, Markovic, Vojvodic, Neskovic, Sethi \& Grbic, 2015; Raleva et al., 2013, WHO, 2014a. 
Од видовите на семејна дисфункционалност со најголема преваленција во Македонија се присутни злоупотребата на алкохол од страна на родител/згрижувач во семејството и насилното однесување врз мајката во семејството. Речиси секој 10-ти родител/згрижувач во семејството злоупотребува алкохол и речиси секоја 10-та жена во семејството е жртва на семејно насилство (Qirjako et al., 2013; Paunovic, 2013; Raleva et al., 2013; WHO, 2014a).

Table 1. Results from the adverse childhood experiences studies among students in several South-East European countries

\begin{tabular}{|c|c|c|c|c|}
\hline $\begin{array}{l}\text { ACE (during the first } \\
18 \text { years of life) }\end{array}$ & $\begin{array}{l}\text { Albania } \\
\text { Total (\%) } \\
(\mathrm{N}=1437) \\
\end{array}$ & $\begin{array}{l}\text { Macedonia } \\
\text { Total (\%) } \\
(\mathrm{N}=1277)\end{array}$ & $\begin{array}{l}\text { Montenegro } \\
\text { Total (\%) } \\
(\mathrm{N}=\mathbf{1 6 0 0 )} \\
\end{array}$ & $\begin{array}{c}\text { Serbia } \\
\text { Total (\%) } \\
(\mathrm{N}=\mathbf{2 3 8 1 )} \\
\end{array}$ \\
\hline Physical abuse & 41,5 & 21 & 24,3 & 11,4 \\
\hline Emotional abuse & 51,1 & 10,8 & 30,4 & 17,8 \\
\hline Sexual abuse & 6 & 12,9 & 3,9 & 5 \\
\hline Physical neglect & 6,5 & 20,9 & 18,8 & 9,5 \\
\hline Emotional neglect & 11,2 & 30,6 & 27 & 15,5 \\
\hline \multicolumn{5}{|l|}{$\begin{array}{l}\text { Household } \\
\text { dysfunction } \\
\end{array}$} \\
\hline $\begin{array}{l}\text { Parent with illicit drug } \\
\text { use }\end{array}$ & 1,6 & 3,6 & 3,6 & NA \\
\hline $\begin{array}{l}\text { Parent with alcohol } \\
\text { misuse }\end{array}$ & 20,5 & 10,7 & 11,9 & 9,1 \\
\hline $\begin{array}{l}\text { Mental illness in the } \\
\text { family }\end{array}$ & 6,8 & 6,9 & 6,1 & 6,6 \\
\hline $\begin{array}{l}\text { Mother being treated } \\
\text { violently }\end{array}$ & 30,1 & 10 & 24 & 18,7 \\
\hline $\begin{array}{l}\text { Incarcerated family } \\
\text { member }\end{array}$ & 3,8 & 5 & 7,8 & NA \\
\hline $\begin{array}{l}\text { Separated/ } \\
\text { divorced parents }\end{array}$ & 6,6 & 3,8 & 10,6 & 12 \\
\hline
\end{tabular}

Source: Qirjako et al., 2013; Paunovic, 2013; Raleva et al., 2013; WHO, 2014b. 
ПРЕВЕНЦИЈА НА ЗЛОУПОТРЕБАТА И

ЗАНЕМАРУВАЊЕТО НА ДЕЦАТА

Превенцијата вообичаено подразбира методи или активности кои бараат да се да се спречи или намали одреден предвидлив проблем, заштита на постоечката благосостојба на популацијата, или промоција на посакувани резултати или однесувања кај одредена популација (Krug et al, 2002; Sethi et al, 2013). Јавно-здравствениот пристап за превенција зборува за три нивоа на превенција: програми за примарна превенција, кои можат да бидат насочени кон општата популација (универзални); секундарна превенција - програми за превенција кои се насочени кон поединци или семејства кај кои постои поголем ризик за злоупотреба и занемарување (повисок ризик); и терцијарни програми за превенција.

Активностите од доменот на примарна превенција се насочени кон општата популација и имаат за цел да ја спречат појавата на злоупотреба и занемарување. Сите членови на заедницата имаат пристап и може да ги користат услугите наменети за општата популација (Krug et al, 2002; Sethi et al, 2013). Активностите во рамките на секундарна превенција се насочени кон поризичните групи од општата популација, односно оние групи кај кои
The most prevalent household dysfunctions in Macedonia are presented to be the parent with alcohol misuse and mother being treated violently. Nearly every $10^{\text {th }}$ parent have misused alcohol and every $10^{\text {th }}$ women has been victim of family violence (Qirjako et al., 2013; Paunovic, 2013; Raleva et al., 2013; WHO, 2014b).

\section{Prevention of ChILd}

\section{MALTREATMENT}

Prevention typically consists of methods or activities that seek to reduce or prevent specific or predictable problems, protect the current state of well-being, or promote desired outcomes or behaviours (Krug et al., 2002; Sethi et al., 2013). Public health framework of prevention consists of three levels of services: primary prevention programs, which can be directed at the general population (universal); secondary prevention programs, which are targeted to individuals or families in which maltreatment is more likely (high risk); and tertiary prevention programs (Krug et al., 2002; Sethi et al., 2013). 
може да има еден или повеќе фактори на ризик поврзани со злоупотреба и занемарување на децата, како што се: сиромаштијата, родители кои злоупотребуваат дрога, родители на млада возраст, родители кои имаат проблеми со менталното здравје, како и родители на дете со посебни потреби. Терцијарната превенција подразбира активности кои се фокусираат на семејствата каде што веќе постои злоупотреба и занемарување и целта е да се намалат негативните последици од злоупотребата и/или да се спречи нејзиното повторување (Krug et al, 2002; Sethi et al, 2013).

Бројните интервенции за превенција на злоупотребата и занемарувањето на децата се спроведуваат во Европскиот регион на С3О, а некои од нив и се евалуираат за нивната ефикасност. Во целина, сепак, доказите за ефективноста на интервенциите бараат дополнителни истражувања. Поголем број на студии се фокусираат на факторите на ризик, како што се родителскиот стрес и родителските практики, додека малобројни се студиите кои се фокусираат на последиците од злоупотребата и занемарувањето (Sethi et al., 2013).

Постојат различни програми за кои постојат одредени докази за нивната ефикасност/ кои ќе бидат објаснети во натамошниот текст/ (Butchart et al., 114
Primary prevention activities can be directed at the general population and attempt to stop the occurrence of maltreatment. All members of the community have access to and may benefit from services directed at the general population. (Krug et al., 2002; Sethi et al., 2013). Secondary prevention activities developed for a high-risk focus are offered to populations that may have one or more risk factors associated with child maltreatment, such as poverty, parental substance abuse, young parental age, parental mental health concerns, and parental or child disabilities. Tertiary prevention activities focus on families where maltreatment has already occurred (indicated) and seek to reduce the negative consequences of the maltreatment and to prevent its recurrence (Krug et al., 2002; Sethi et al., 2013).

Numerous interventions to prevent child maltreatment are now being implemented in European settings, with some being tested for effectiveness. In general, however, the evidence base on the effectiveness of interventions needs additional research. Most studies focus on risk factors, such as parental stress and parenting practices, and few use actual child maltreatment outcomes (Sethi 
2006; Sethi et al., 2013).

Програмите за домашна посета вклучуваат посети од страна на медицински сестри во домовите на родителите и децата, за да се превенира злоупотребата и занемарувањето на децата, преку обезбедување на поддршка, образование и информации.

Програмите за позитивно родителство имаат за цел да ги унапредат знаењата на родителите за детскиот развој, да ги зголемат нивните родителски вештини и да го зајакнат нивниот однос со децата.

Програмите за превенција на сексуалната злоупотреба подразбираат обука за препознавање и одбегнување на потенцијални ситуации на сексуална злоупотреба, кои вообичаено се спроведуваат во училиштата.

Превенција на травматска повреда на главата е сериозна форма на злоупотреба кај децата, која може да резултира со сериозни повреди на мозокот, вратот, или спинална повреда. Често е позната како "shaken baby" or "shaken infant" синдром, како резултат на повредите здобиени од насилното тресење на бебето од страна на нивните родители/згрижувачи (во одговор на пример на фрустрација на плачење на бебето), (Sethi et al., 2013).

Медиумските кампањи за зголемување на јавната свест имаат за цел да ја споделат пораката со пошироката et al., 2013).

There are a various preventive programmes and we will discuss the ones that have been some evidence on effectiveness (Butchart et al., 2006; Sethi et al., 2013). Early home visiting programmes involve visits by nurses to parents and children in their homes to prevent child maltreatment and promote positive infant, child and parental development by providing support, education and information. Parenting programmes aim to improve parents' knowledge of child development, increase their parenting skills and strengthen relationships with their children. Child sexual abuse prevention is anticipating training to recognize and avoid potentially sexually abusive situations is usually delivered in schools. Prevention of abusive head trauma, which is a severe form of child abuse that can result in serious brain, neck and spinal injury. It is often referred to as "shaken baby" or "shaken infant" syndrome, due to injuries commonly being sustained through violent shaking of infants by their caregivers (in response, for example, to frustration at crying), (Sethi et al., 2013). Media-based public awareness programmes aim to disseminate messages among the gener- 
јавност, користејќи ги следниве медиуми: телевизија, радио, печатени материјали и интернет.

Предучилишните и училишните програми обезбедуваат предучилишна или училишна едукација за децата. Тие имаат за цел: да ги образуваат децата во врска со основните вештини на активно слушање, емпатија, решавање на проблеми и поддржување; обука да ги препознаат потенцијалните повредувачки ситуации и унапредување на социјалните вештини.

Обука за социјални вештини и социјално-развојни програми кои може да бидат индивидуални или групни и насочени кон: справување со лутината, градење на социјални вештини и самодоверба, обука како да го спречи насилството и сл., (Sethi et al., 2013).

Програмите за менторство подразбираат вклучување на повозрасен позитивен модел кој ќе воспостави пријателски и поддржувачки однос за да ги заштити децата и адолесцентите од вклучување во насилство.

Училишните анти-булинг програми може да имаат различни форми за деца кои веќе се вклучени во булинг. Врсничките интервенции подразбираат помош во основните вештини за активно слушање, емпатија, решавање на проблеми, поддржувачко однесување со цел да им помогне на младите кои се вклучени во ситуации на булинг. 116 al population using channels such as television, radio, printed materials and the Internet (Sethi et al., 2013). Preschool and school enrichment programmes provide preschool and school education for young children. They aim to: educate children about basic skills of active listening, empathy, problem solving and supportiveness; teach them to recognize potentially harmful situations; and teach them to improve social skills. Life skills and social development programmes can take different forms. Individualized or group interventions can provide anger management, social skills and assertiveness training for children to prevent violence (Sethi et al., 2013). Mentoring programmes assume that a warm and supportive relationship with a positive role model can help to protect children and adolescents against involvement in youth violence. After-school programmes extend adult supervision and aim to improve children's academic achievement and school involvement by supporting their studies and offering recreational activities outside normal school hours (Sethi et al., 2013). School anti-bullying can take different forms for children already involved in bullying. Peer-led interventions teach 
Медицинско-правните служби се наменети за случаи на сексуална злоупотреба. Тие обезбедуваат директна медицинска и психосоцијална поддршка, правни совети за жртвите и прибирање на медицински и правни докази за справување во постапките со сторителите.

Податоците од оценката на Глобалниот извештај за состојбата со превенција на насилството, 2014 година покажуваат дека некои програми за превенција на злоупотребата и занемарувањето на децата кај нас се спроведуваат, додека пак други е потребно да се унапредат (WHO, 2014c). Предучилишните и училишни програми кај нас се спроведуваат во поголем обем. Програмите за домашни посети, таканаречени поливалентни патронажни служби, се составен дел на системот за јавно здравство, што е организациска единица во рамките на установите за јавно здравство коишто ја изведуваат дејноста на поливалентни патронажни услуги од превентивна и куративна природа, а со кои се покрива целото семејството преку посетите на патронажните сестри дома и во соработка со здравствените и други установи на нивната територија (Health Insurance Fund of Macedonia, 2016).

Друга програма која се спроведува во поголема мера кај нас се дополнителните предучилишни и училишни peer helpers the basic skills of active listening, empathy, problem solving and supportiveness that they need to help others involved in a bullying situation. Medico-legal services for sexual abuse provide immediate medical and psychosocial care and legal advice for victims, and collect medical and legal evidence to corroborate victim accounts and help identify perpetrators (Sethi et al., 2013).

The data on the implementation of the preventive programmes in Macedonia are gathered from the assessment of the Global status report on violence prevention 2014 (WHO, 2014c). The findings show that some child maltreatment prevention programmes are implemented on a larger scale, while others need to be scaled up. Home-visit programmes and preschool and school enrichment programmes are implemented in the country on a larger scale. Home-visit programmes characterised as polyvalent patronage service, is an integral part of the system of public health, organizational unit within the public health institution that implements polyvalent nursing activity in services of preventive-curative nature and covers the entire family through visits of the nurses at home and cooperation with health and 
програми. Македонија има долга традиција на државно финансирана предучилишна грижа и образование. Се очекуваше градинките да им помогнат на родителите, така што ќе обезбедат целодневен престој. Податоците покажаа дека стапката на запишување на децата на возраст од 36-59 месеци се зголемила на национално ниво од $11 \%$ во 2006 на 22\% во 2011 година, додека пак зголемувањето на оваа стапката кај маргинализираните групи деца и понатаму е многу ниска, кај етничките Албанци од 1,5 на 3\%, кај етничките Роми од 3,5 на 4\%, а пак во руралните средини од 1,5 на 6\% (UNICEF; 2014).

Другите програми, како што се: програми за родителство, обука за препознавање/одбегнување на ситуации на злоупотреба, програми за развој на животните вештини и општествен развој, менторство, анти-булинг програми во училиштата се спроведуваат во помала мера. Потребно е да се направи евалуација на програмите со цел да се планираат идните програми засновани на докази кои би можеле да се спроведуваат.

\section{ДИСКУСИЈА НА НАЦИОНАЛНИТЕ}

ПОЛИТИКИ, ЗАКОНСКАТА

РЕГУЛАТИВА И ИДНИТЕ НАСОКИ

Превенцијата и заштитата на децата од злоупотреба и занемарување во 118 other facilities on its territory (Health Insurance Fund of Macedonia, 2016).

Other programmes implemented on the larger scale are preschool and school enrichment programmes. Macedonia has a strong tradition of state-funded preschool care and education. Expectations were that kindergartens should support working parents by providing full day care. The data showed that the enrolment rate among children aged 3659 months increased at national level from $11 \%$ in 2006 to $22 \%$ in 2011, while the increase for marginalized groups of children was very limited: among ethnic Albanians from 1.5 to 3, ethnic Roma from 3.5 to $4 \%$, and rural from 1.5 to $6 \%$ (UNICEF; 2014).

The programmes such as: parenting programme, training to recognize/avoid abusive situations, life skills and social development programmes, mentoring, school anti-bullying and others are implemented on a smaller scale. Evaluation of the programmes is needed in order to plan future implementation of informed evidence-based programmes. 
Република Македонија се предвидени со неколку стратешки документи и соодветна законска регулатива. Со усвојување на Националниот акционен план за превенција и заштита од злоупотреба и занемарување на децата (2013-2015) за прв пат во земјава сеопфатно се предвидоа стратегиски интервенции за заштита и превенција на злоупотребата и занемарувањето на децата, иако поголем акцент беше ставен на заштитата, отколку на превенцијата (Министерство за труд и социјална политика и Министерство за здравство на Република Македонија, 2013а). Неопходна е евалуација на спроведувањето на Националниот акционен план, која би послужила како основа развивање на нов Националниот акционен план за превенција и заштита на злоупотребата и занемарувањето на децата со нова временска рамка и ревидирани приоритети во согласност со контекстот.

Дополнително, преку Националната стратегија за превенција и заштита од семејно насилство (2012-2015), се предвидуваат мерки за превенција на злоупотреба и занемарување на децата во контекст на семејството и заштита од семејното насилство (Министерство за труд и социјална политика на Република Македонија, 2013б).

Акциониот план за превенција и заштита од сексуалната злоупотреба

\section{Discussing National POLICIES, Le-} GAL FRAMEWORK AND FUTURE DIRECTIONS

The prevention and protection of child maltreatment in Macedonia has been anticipated by several policy and legal documents. With adoption of the National Action Plan for Prevention and Prevention of Child Abuse and $\mathrm{Ne}$ glect (2013-2015) for the first time the country has comprehensively envisaged policy interventions for protecting and preventing child maltreatment, although more emphasis was put on protection (Ministry of Labor and Social Policy and Ministry of Health, 2013a). The evaluation of the implementation of this action plan is needed as a basis for the development of a new Action Plan Prevention and Combating Child Abuse and Neglect with the new timeframe and updated priority settings.

Additionally, the National Strategy for prevention and protection domestic violence (2012-2015) has included prevention of child abuse and neglect within context of the priorities of domestic violence protection (Ministry of Labor and Social Policy, 2013b). 
на децата и педофилија (2009-2012) се фокусира врз превенцијата и заштитата на децата од сексуална злоупотреба (Министерство за труд и социјална политика на Република Македонија, 2013в).

Друг значаен стратешки документ e, секако, Националната стратегија за намалување на сиромаштијата и социјалната исклученост (2010-2020) со која се засегнуваат правата на децата, вклучувајќи ги и правата на социјалната заштита, социјалната вклученост, здравството, образованието, и вработувањето (Министерство за труд и социјална политика на Република Македонија, 2010).

Националниот акционен план за правата на детето (2012-2015) има за цел да ја промовира еднаквоста, инклузивноста, како и ефикасноста во давањето услуги за децата, како што се здравствената заштита и образованието (Министерство за труд и социјална политика на Република Македонија, 2012б).

Акциониот план за децата на улица/ уличните деца (2013-2015) е насочен кон справување со негативните последици од работната експлоатација на децата на улица преку обезбедување на потребните услуги, вклучително и образованието (Министерство за труд и социјална политика на Република Македонија, 2013г).
Action Plan for Prevention and Combatting Sexual Abuse of Children and Pedophilia (2009-2012), focuses on prevention and protection of children from sexual abuse (Ministry of Labor and Social Policy, 2013c).

Another policy document is the National Strategy for the Fight against Poverty and Social Exclusion, 2010-2020 that addresses children's rights, including social protection, social inclusion, health, education, and employment Ministry of Labor and Social Policy, 2010). National Plan of Action on the Rights of the Child (2012-2015) aims to promote equity, inclusion, and efficiency in the provision of services for children such as health care and education (Ministry of Labor and Social Policy, 2012b).

Action Plan for Street Children (2013-2015) addresses combating harmful effects of street work by providing such children services including education (Ministry of Labor and Social Policy, 2013d). All these policy documents are solid policy basis for prevention and protection of children from abuse and neglect. On the other hand, more efforts are needed in ensuring that the policies are implemented with adequate resources allocated for the antici- 
Сите овие национални политики претставуваат значајна основа за превенција и заштита на децата од злоупотреба и занемарување. Од друга страна, сепак, потребни се поголеми напори во имплементација на истите и обезбедување соодветни средства со кои ќе се гарантира реализација на предвидените активности и услуги.

Со постоечката законска регулатива во Македонија беше направена адекватна основа за заштитата на правата на децата, вклучувајќи и́ превенција и заштита на децата од злоупотреба и занемарување. Законот за заштита на децата го уредува системот, организацијата и начините на кои се обезбедува детската заштита („Сл. весник на Република Македонија“ бр. 23/13, 12/14, 44/14, 144/14, бр.10/15, бр. $25 / 15$, бр.150/15, 192/15 и 27/16).

Законот за семејство ги обезбедува заштитните и репресивните мерки на заштита на правата и интересите на децата преку правата и обврските на Центрите за социјална работа, кои го мониторираат начинот на родителското право („Сл. весник на Република Македонија“ бр. 80/1992, 9/1996, 38/2004, 33/2006, 84/2008, 67/10, $156 / 10, \quad 39 / 12, \quad 44 / 12, \quad 38 / 14,115 / 14$, $104 / 15$ и $150 / 15)$.

Понатаму, преку законот за основно образование („Службен весник на Република Македонија“ бр. 103/2008, pated activities and services.

With the actual legal framework Macedonia has made a suitable ground for protection of children rights including prevention and protection of children from abuse and neglect. The Law on Child Protection regulates the system, the organization and the manner of providing protection to the children (Official Gazette of the R.M., No. 23/13, 12/14, 44/14, 144/14, 10/15, бp.25/15, бp.150/15, 192/15, 27/16).

The Family Law provides preventive and repressive measures of protection of the rights and the interests of the child through the right and duty of the Centres for Social Work to monitor the exercise of the parental right (Official Gazette of the R.M., No. 80/1992, 9/1996, 38/2004, 33/2006, 84/2008, 67/10, 156/10, 39/12, $44 / 12,38 / 14,115 / 14,104 / 15$ и 150/15).

The Law on Primary Education (Official Gazette of the R.M., No. 103/2008, $33 / 2010,116 / 2010,156 / 2010,18 / 2011$, 42/2011, 51/2011, 6/2012, 100/2012, 24/2013, 41/2014, 116/2014, 135/2014, $10 / 2015,98 / 2015,145 / 2015,30 / 2016$ и 127/16) especially article 53, prohibit the use of corporal punishment and psychological maltreatment. With the Law on Secondary Education (Official Ga- 
$33 / 2010,116 / 2010,156 / 2010,18 / 2011$, 42/2011, 51/2011, 6/2012, 100/2012, 24/2013, 41/2014, 116/2014, 135/2014, $10 / 2015,98 / 2015,145 / 2015,30 / 2016$ и 127/16) член 53 се забранува телесна и психичка злоупотреба на ученикот. Со Законот за средно образование („Службен весник на Република Македонија“ бр. 44/1995, 24/1996, 34/1996, 35/1997, 82/1999, 29/2002, 40/2003, 42/2003, 67/2004, 55/2005, 113/2005, $35 / 2006,30 / 2007,49 / 2007,81 / 2008$, 92/2008, 33/2010, 116/2010, 156/2010, $18 / 2011 ， 42 / 2011 ， 51 / 2011 ， 6 / 2012$, 100/2012, 24/2013, 41/2014, 116/2014, $135 / 2014,10 / 2015$, 98/2015, 145/2015, 30/2016 и 127/2016) се забранува дискриминација на децата по основ на пол, раса, боја на кожа, национална, социјална, политичка и религиозна припадност, материјална или класна положба во општеството

Со Законот за социјална заштита („Службен весник на Република Македонија» бр. 79/09, 36/11, 51/11, $166 / 12,15 / 13,79 / 13,164 / 13,187 / 13$, $38 / 14,44 / 14,116 / 14,180 / 14,33 / 15$, $72 / 15,104 / 15,150 / 15,173 / 15$ и $30 / 16$ ), се предвидува систем на мерки, активности и политики за спречување и надминување на основните социјални ризици на кои се изложени децата, за намалување на сиромаштијата и социјалната исклученост и за јакнење на капацитетот за сопствената заштита. zette ofthe R.M., No. 44/1995, 24/1996, 34/1996, 35/1997, 82/1999, 29/2002, 40/2003, 42/2003, 67/2004, 55/2005, 113/2005, 35/2006, 30/2007, 49/2007, 81/2008, 92/2008, 33/2010, 116/2010, 156/2010, 18/2011, 42/2011, 51/2011, 6/2012, 100/2012, 24/2013, 41/2014, 116/2014, 135/2014, 10/2015, 98/2015, $145 / 2015,30 / 2016$ и 127/2016) prohibit discrimination on the grounds of sex, race and colour of skin, as well as national, social, political, religious affiliations, property status and class in the society.

The Law on social protection (Official Gazette of the R.M., No. 79/09, $36 / 11,51 / 11,166 / 12,15 / 13,79 / 13$, 164/13, 187/13, 38/14, 44/14 , 116/14, $180 / 14,33 / 15,72 / 15,104 / 15,150 / 15$, $173 / 15,30 / 16)$ envisaged are system of measures, activities and policies for preventing and overcoming basic social risks to which children are exposed, reducing poverty and social exclusion and strengthening the capacity for their own protection.

Law on Health Care provides preventive, diagnostic, therapeutic and rehabilitative procedures. Health care for a child-victim of abuse is a guaranteed right according to this Law (Offi- 
Со Законот за здравствена заштита се овозможуваат превентивни, дијагностички, терапевтски и рехабилитациони процедури. Согласно со овој закон, здравствената заштита е загарантирано право на дете жртва на злоупотреба (,Службен весник на Република Македонија“" бр. 43/2012, 145/2012, 87/2013, 164/2013, 39/2014, 43/2014, 132/2014, 188/2014 и 10/2015). Законот за здравствено осигурување овозможува задолжително здравствено осигурување за децата на возраст под 18 години, кои имаат право да ги добијат сите здравствени услуги од здравствените установи. Согласно со овој закон, секој облик на злоупотреба и занемарување на детето потпаѓа под задолжителната здравствена заштита на детето (,Службен весник на Република Македонија“ број 25/2000, 96/2000, 50/2001, 11/2002, 31/2003, 84/2005, 37/2006, 18/2007, 36/2007, 82/2008, 98/2008, 6/2009, 67/2009, 50/2010, 156/2010, 53/2011, 26/2012, 16/2013, 91/2013, 187/2013, 43/2014, $44 / 2014,97 / 2014,112 / 2014$ и 113/2014).

Со внесување на законските измени во споменатите закони, телесното казнување на децата се забранува во сите контексти (дома, училиште, и други институции). Со тоа, Македонија стана една од земјите-членки со соодветно законодавство, со цел да се стави крај на телесното казнување cial Gazette of the

R.M., No.

43/2012, 145/2012, 87/2013, 164/2013, 39/2014, 43/2014, 132/2014, 188/2014 и 10/2015).

The Law on Health Insurance (Official Gazette of the R.M., No. 25/2000, 96/2000, 50/2001, 11/2002, 31/2003, 84/2005, 37/2006, 18/2007, 36/2007, 82/2008, 98/2008, 6/2009, 67/2009, 50/2010, 156/2010, 53/2011, 26/2012, 16/2013, 91/2013, 187/2013, $43 / 2014,44 / 2014,97 / 2014,112 / 2014$ и $113 / 2014$ ) provide for mandatory health insurance for children under 18 who are entitled to receive all medical services in health care institutions. According to this Law, any form of abuse and neglect of a child falls under compulsory health care for a child. Also legal acts have been adopted against child marriage, against statutory rape, and against female genital mutilation.

With the legal changes in several laws, ban of corporal punishment in all settings has enabled Macedonia to become country with satisfactory legislation to end corporal punishment against children. Although we have a law on ban of corporal punishment in all settings, studies conducted in the country reviled that still violent discipline is the 
на децата. Иако имаме закони кои го забрануваат телесното казнување во сите средини, студиите спроведени во земјава укажуваат дека насилното воспитување или телесното казнување на децата сѐ уште претставува најзастапениот вид на дисциплинирање на децата со околу $72 \%$ родители кои ги користат овие практики. Еден од најзначајните предизвици кој останува допрва да се надмине е всушност поддршка и јакнење на спроведувањето на постоечките измени во законите (Global Initiative to End All Corporal Punishment of Children, 2014).

Постигнувањето на ефективно влијание врз децата и нивните семејства бара континуирани напори во развивањето и евалуирањето на бројните превентивни програми и системските реформи. Во согласност со препораките на С3О за Европа и контекстот на Република Македонија клучни предизвици и можности за унапредување на заштитата и превенцијата на злоупотреба и занемарување на деца вклучуваат (Krug et al., 2002; Sethi et al., 2013):

Унапредување на можноста за опфат на најризичните групи и јакнење на мултисекторската соработка. Најчестите фактори кои ги идентификуваат популациите под ризик за злоупотреба и занемарување вклучуваат возраст, сиромаштија, еднородител124 most common way of discipline children with around $70 \%$ of parents using these practice for their child. One of the major challenges remains yet to be critically fulfilled in the area of legal framework and that is the implementation and strengthening the law enforcement (Global Initiative to End All Corporal Punishment of Children, 2014).

Achieving stronger impacts with young children and their families will require continued efforts at developing and testing a broad array of prevention programs and systemic reforms. In line with the WHO recommendations and country context the key challenges and the opportunities include the following (Krug et al., 2002; Sethi et al., 2013):

\section{Improving the ability to reach} those at risk and strengthen the multi-sectorial collaboration. The most common factors used to identify populations at risk for maltreatment include young maternal age, poverty, single parent status and severe personal challenges such as domestic violence, substance abuse, and mental health issues. Building on a public health model of integrated services, child abuse prevention strategies may be more efficiently allocated by embedding such services 
ски семејства, семејства каде постои семејното насилство, злоупотребата на дроги и проблеми во менталното здравје. Развојот на јавно-здравствениот модел на интегрирани служби се смета за најадекватен, бидејќи стратегиите за превенција на злоупотребата и занемарувањето би можеле да бидат вградени во рамки на постоечките јавно-здравствени служби за проценка, помош и грижа. (Krug et al., 2002; Sethi et al., 2013). Системот би бил многу поефикасен доколку здравствениот, социјалниот, полицискиот, образованиот и правосудниот сектор би работеле преку координиран приод на испорачување на квалитетни услуги за евидентирање, откривање, третирање, превенирање и заштита на децата. Законската основа за координирано постапување постои, но спроведувањето бара дополнително зајакнување.

\section{Спроведување на превентивни} програми засновани на докази. Повеќето служби што ги обезбедуваат институциите во земјава се фокусирани врз откривањето на злоупотребата и заштитата на децата од понатамошна злоупотреба и занемарување. Затоа, треба да се стави поголем акцент врз спроведување на превентивните програми засновани на докази, како што ce домашните посети, позитивното родителство, превенција на травматска повреда на главата како последица within a universal system of assessment and support (Krug et al., 2002; Sethi et al., 2013). The system will be more efficient if the health, social, police, education and justice sectors would adopt a coordinated approach to delivering quality services for recording, detecting, treating, preventing and protecting children. The legal basis for acting is ensured but, the implementation would need additional enforcement.

\section{Implement evidence-based pre-} ventive programmes. The majority of services provided by institutions in the country are focused on detecting abuse and protecting children from further maltreatment. More emphasis should be placed on implementing evidence-based prevention programmes such as home visits, positive parenting, preventing abusive head trauma, preventing early marriages, teaching children to recognize abusive adults and how to resist them, and pre-school and school preventive programmes. Attention is needed in preventive programmes that are indirectly contributing to prevention and reduction of child maltreatment, by prevention and treatment of drug use and harmful use of alcohol (WHO, 2014a; Krug et al., 2002). 
на злоупотреба, превенција на бракови на рана возраст, учење на децата како да ги препознаат насилните возрасни лица и како да им се спротивстават, како и предучилишни и училишни превентивни програми. Потребно е, исто така, да се обрне поголемо внимание на превентивните програми кои индиректно придонесуваат за намалување на злоупотребата и занемарувањето на децата, преку превенција и третман на злоупотреба на дроги и алкохол (WHO, 2014a; Krug et al., 2002).

\section{Унапредување на националните} политики и ефикасно спроведување на законите. Иако во 2013 година беше изработен Националниот акционен план за превенција и заштита на децата од злоупотреба и занемарување, потребно е негово ревидирање, за да се стави поголем акцент врз превенцијата и намалувањето на сите облици на насилството врз децата. Исто така, потребно е посистематско спроведување на законите за забрана на телесното казнување (Global Initiative to End All Corporal Punishment of Children, 2014). Државата треба да ги промовира и поттикне ненасилните облици на дисциплинирање на децата, како алтернативи на телесното казнување, преку медиумски кампањи и менување на традиционалните норми во врска со насилното воспитување на децата (Butchart et al., 2006; Sethi et al., 2013).

\section{Improving national polices and} law enforcement. Although a national action plan on child maltreatment have been developed in 2013, there is a need for revision of an action plan with more emphasis on the prevention and reduction of the all forms of violence against children. The law enforcement on corporal punishment is needed to be implemented more systematically (Global Initiative to End All Corporal Punishment of Children, 2014). The country should promote and encourage non-violent forms of discipline as alternatives to corporal punishment through social marketing campaigns, by changing the traditional norm of violent disciplining (Butchart et al., 2006; Sethi et al., 2013).

\section{Determining how best to intervene} with diverse inequalities. The relevant data suggest that the development of national and local action plans and programmes should anticipate social inequalities such as rural/urban, regional, socioeconomic and familial. Much has been written about the importance of parenting and early intervention programs. Far less emphasis has been placed on testing the differential effects of evidence-based prevention programs on specific diverse inequality groups 
Одредувањето како најдобро да се интервенира со различни нееднаквости. Релевантните податоци укажуваат на тоа дека развојот на националните и локалните акциони планови и програми треба да ги предвидат социјалните нееднаквости, како што се рурално/урбано, регион, социо-економските и семејните фактори. Многу податоци се достапни за важноста на родителството и програмите за рана интервенција. Помал акцент е ставен на проценка на различите ефекти на програмите за превенција на различни популациони групи според одредена социјална нееднаквост (Butchart et al., 2006; Sethi et al., 2013).

Унапредување на следењето, проценката и истражувањата. Податоците за злоупотреба и занемарување не се јавно достапни, ниту пак се достапни податоци според пол и возраст. Системот за прибирање на податоци укажува на потребата од негово унапредување преку стандардизиран приод во собирањето на валидни податоци. Истражувањата и анкетите треба да се спроведуваат на редовна основа, со цел да се измери напредокот во намалувањето на оптовареноста од злоупотребата и занемарувањето на децата, согласно со методологиите предложени од страна на С3O (Butchart et al., 2006; Sethi et al., 2013).
(Butchart et al., 2006; Sethi et al., 2013). Improve monitoring, evaluation and research. Data are not publicly available on child abuse and neglect official statistics. They are not disaggregated data by age and sex. The system indicates the requirement for improving the system for data collection, also needs strengthening in order to adopt standardized approaches in collection of valid data. Studies and surveys should be conducted on a regular basis in order to measure the progress in reduction of the burden of child abuse and neglect as per WHO suggested methodologies (Butchart et al., 2006; Sethi et al., 2013).

\section{Conclusion}

Preventing and protecting child abuse and neglect is not simply a matter of parents doing a better job, but rather it is about creating a context in which "doing better" is easier. Progressive public policy and the replication of evidence-based interventions are only part of what is needed to successfully combat child abuse. It remains important to increase public awareness that child abuse and neglect are serious threats to 


\section{ЗАклУчок}

Превенцијата и заштитата на злоупотребата и занемарувањето на децата не е само прашање на тоа дека родителите „прават подобра работа“, туку тоа подразбира создавање на контекст во кој „постапувањето подобро“ е поедноставно. Постоење на прогресивна национална стратешка рамка и креирање на интервенции засновани на докази се само дел од она што е неопходно да се направи, за да се справиме со злоупотреба и занемарувањето на децата. Останува неопходно да се зголеми јавната свест за тоа дека злоупотребата и занемарувањето на децата претставуваат сериозна закана за детскиот развој и, исто така, дека насилството врз децата, како и недостатокот на грижа и супервизија се неприфатливи. Индивидуите имаат лична одговорност да се насочат кон намалување на актите на злоупотреба и занемарување на децата, преку обезбедување на поддршка и заштита на сите деца во рамките на нивните семејства и заедници. a child's healthy development and that evident violence toward children and a persistent lack of care and supervision are unacceptable. Individuals have the ability to accept personal responsibility for reducing acts of child abuse and neglect by providing support to each other and offering protection to all children within their family and their community. 


\section{ЛИТЕРАТУРА}

Belsky, J. (1980). Child maltreatment: An ecological integration. American Psychologist, 35, 320-335.

Butchart, A., Harvey, A. P., Mian, M., \& Furniss, T. (2006). Preventing child maltreatment: a guide to taking action and generating evidence. Geneva: World Health Organization and International Society for Prevention of Child Abuse and Neglect.

Bronfenbrenner, U. (1993). Ecological model of human development. International Encyclopedia of Education, 3.

Donnelly, M., \& Straus, M. A. (2005). Corporal punishment of children in theoretical perspective. New Haven, CT: Yale University Press.

Durrant, J., \& Ensom, R. (2012). Physical punishment of children: lessons from 20 years of research. Canadian Medical Association Journal, 184, (13), 73-1376.

Ferguson, C.J. (2013). Spanking, corporal punishment and negative long-term outcomes: A meta-analytic review of longitudinal studies. Clinical Psychology Review, 33, 196-208.

Фонд за здравствено осигурување. ФЗО, 2016, http://www.fzo.org.mk/default.as $\mathrm{p}$ ?ItemID=6C8BDADE268D2D489302275C6FF87F2E.

Gershoff, E.T. (2010). More harm than good: A summary of scientific research on the intended and unintended effects of corporal punishment on children. Law and Contemporary Problems. 73(2), 31-56.

Gershoff, E.T. (2013). Spanking and child development: We know enough now to stop hitting our children. Child Development Perspectives,7 (3), 133-137.

Global Initiative to End All Corporal Punishment of Children. (2014). Prohibiting all corporal punishment of children: progress and delay-Progress toward prohibiting all corporal punishment. Briefing prepared by the Global Initiative to End All Corporal Punishment of Children.

Gray J., Jordanova Pesevska, D., Sethi, D., Ramiro González, M.D. \& Yon Y. (2016). Handbook on developing national action plans to prevent child maltreatment. Copenhagen: World Health Organization. 
Jordanova Peshevska, D., Tozija, F., Jordanova, T., Vaskova, P., \& Vaskova I. (2016). Implementing Sustainable Development Goals by Preventing Child Abuse and Neglect. Eurodialogue, 22, 291-304.

Kempe, C.H., Silverman F.N., Steele, B.F., Droegemueller, W., \& Silver, H.J. (1962). The battered-child syndrome. JAMA, 7 (181), 17-24.

Krug, E.G., Dahlberg, L.L., Mercy, J.A., Zwi, A.B., \& Lozano, R. (2002). World report on violence and health. Geneva: World Health Organization.

Министерство за труд и социјална политика на Република Македонија. (2010). Национална стратегија за намалување на сиромаштијата и социјалната исклученост, 2010-2020 година . Скопје: Министерство за труд и социјална политика на Република Македонија.

Министерство за здравство, Министерство за образование и наука, Министерство за труд и социјална политика на Република Македонија. (2012а).

Мултииндикаторско кластерско истражување, 2011 година. Скопје: Министерство заздравство, Министерство за образование и наука, Министерство за труд и социјална политика на Република Македонија.

Министерство за труд и социјална политика на Република Македонија. (2012б). Национален акционен план за правата на детето (2012-2015). Скопје: Министерство за труд и социјална политика на Република Македонија. Министерство за труд и социјална политика и Министерство за здравство на Република Македонија. (2013а). Национален акционен план за превенција и заштита на злоупотребата и занемарувањето на децата (2013-2015). Скопје: Министерство за труд и социјална политика и Министерство за здравство на Република Македонија.

Министерство за труд и социјална политика на Република Македонија. (2013б). Национална стратегија за превенција и заштита од семејно насилство (2012 2015). Скопје: Министерство за труд и социјална политика на Република Македонија. 
Министерство за труд и социјална политика на Република Македонија. (2013в).

Акционен план за превенција и борба против сексуална злоупотреба на децата и педофилија (2009-2012). Скопје: Министерство за труд и социјална политика на Република Македонија.

Министерство за труд и социјална политика на Република Македонија. (2013г). Акционен план за деца на улица (2013-2015). Скопје: Министерство за труд и социјална политика на Република Македонија.

Pinheiro, S.P. (2006). World report on violence against children. Geneva: United Nations United Nations Secretary-General's Study on Violence against Children. Paunovic, M., Markovic, M., Vojvodic, K., Neskovic, A., Sethi, D., \& Grbic M. (2015). Survey of adverse childhood experiences among Serbian university students. Copenhagen: World Health Organization, Regional Office for Europe. Qirjako, G., Burazeri, G., Sethi, D., \& Miho V. (2013). Community survey on prevalence of adverse childhood experiences in Albania. Copenhagen: World Health Organization.

Raleva, M., Jordanova Peshevska, D., Sethi, D. (2013). Survey of Adverse Childhood Experiences among Young People in the former Yugoslav Republic of Macedonia.

Copenhagen: World Health Organization, Regional Office for Europe.

Sethi, D., Bellis, M., Hughes, K., Gilbert, R., Mitis, F., \& Galea, G. (2013).

European report on preventing child maltreatment. Copenhagen: World Health Organization, Regional Office for Europe.

Sethi, D., \& Jordanova Peshevska, D. (2014). Preventing Interpersonal Violence in Europe. Macedonian Journal for Medical Sciences, 7, 346-348. doi.org/10.3889/ MJMS.1857.5773.2014.0419.

Tozija, F., Gjorgjev, D., Kjosevska, E., \& Kendrovski, V. (2008). 2007/2008 Global School Based Student Health Results, Republic of Macedonia. Skopje: Republic Institute for Health Protection.

Tozija, F., Jordanova Peshevska, D., (2016). Translating Knowledge into Violence Prevention Policy towards the Sustainable Development Goals in the Republic of Macedonia. Eurodialogue, 22, 262-282. 
UNICEF. (2010). Child Disciplinary Practices at Home: Evidence from a Range of Low- and Middle Income Countries. New York: UNICEF.

UNICEF. (2014). UNICEF Annual Report 2014 Former Yugoslav Republic of Ma cedonia. Skopje: UNICEF.

United Nations General Assembly, Convention on the Rights of the Child, 1989, Retrieved from: http://srsg.violenceagainstchildren.org/sites/default/files/ documents/docs/A RES-44-25_EN.pdf

Влада на Република Македонија. Закон за заштита на децата („Сл. весник на Република Македонија““ бр.23/13, 12/14, 44/14, 144/14, 10/15, 25/15, 150/15). Влада на Република Македонија.

Влада на Република Македонија. Закон за семејството („Сл. весник на Република Македонија“ бр. 80/1992, 9/1996, 38/2004, 33/2006, 84/2008, 67/10, $156 / 10,39 / 12,44 / 12,38 / 14,115 / 14,104 / 15$ и 150/15). Влада на Република Македонија.

Влада на Република Македонија. Закон за основно образование („Службен весник на Република Македонија““ бр. 103/2008, 33/2010, 116/2010, 156/2010, 18/2011, 42/2011, 51/2011, 6/2012, 100/2012, 24/2013, 41/2014, 116/2014, $135 / 2014,10 / 2015,98 / 2015,145 / 2015,30 / 2016$ и 127/16). Влада на Република Македонија.

Влада на Република Македонија. Закон за средно образование („Службен весник на Република Македонија“ бр. 44/1995, 24/1996, 34/1996, 35/1997, 82/1999, 29/2002, 40/2003, 42/2003, 67/2004, 55/2005, 113/2005, 35/2006, 30/2007, 49/2007, 81/2008, 92/2008, 33/2010, 116/2010, 156/2010, 18/2011, 42/2011, 51/2011, 6/2012, 100/2012, 24/2013, 41/2014, 116/2014, 135/2014, $10 / 2015,98 / 2015,145 / 2015,30 / 2016$ и 127/2016). Влада на Република Македонија.

Влада на Република Македонија. Закон за социјалната заштита („Службен весник на Република Македонија» бр. 79/09, 36/11, 51/11, 166/12, 15/13, 79/13, 164/13, 187/13, 38/14, 44/14 , 116/14, 180/14, 33/15, 72/15, 104/15, 150/15, 173/15, 30/16). Влада на Република Македонија. 
Влада на Република Македонија. Закон за здравствена заштита („Службен весник на Република Македонија“ бр. 43/2012, 145/2012, 87/2013, 164/2013, 39/2014, 43/2014, 132/2014, 188/2014 и 10/2015). Влада на Република Македонија.

Влада на Република Македонија. Закон за здравствено осигурување („Службен весник на Република Македонија“ број 25/2000, 96/2000, 50/2001, 11/2002, 31/2003, 84/2005, 37/2006, 18/2007, 36/2007, 82/2008, 98/2008, 6/2009, 67/2009, 50/2010, 156/2010, 53/2011, 26/2012, 16/2013, 91/2013, $187 / 2013,43 / 2014,44 / 2014,97 / 2014,112 / 2014$ и 113/2014). Влада на Република Македонија.

World Health Organization. (1999). Social Change and Mental Health, Violence and Injury Prevention. Report of the Consultation on Child Abuse Prevention, 29-31 March 1999. Geneva: WHO.

World Health Organization Assembly Resolution WHA56.24 (2003). Retrieved from http://www.who.int/features/2003/05b/en/

World Health Organization (2005). WHO Regional Committee for Europe resolution EUR/RC55/R9 on prevention of injuries in the WHO European Region. Copenhagen: WHO Regional Office for Europe. Retrieved from http://www.euro.who.int/_data/assets/pdf_file/0017/88100/RC55_eres09.pdf World Health Organization. (2012). European Health 2020: a European policy framework supporting action across government and society for health and well-being. Copenhagen: World Health Organization, Regional Office for Europe.

World Health Organization. (2013). Global health estimates - Disease and injury regional estimates 2000-2011 [on line data base]. Geneva: Author. Retrieved from http://www.who.int/healthinfo/global_burden_disease/en/

World Health Organization. (2014a). WHO Regional Committee for Europe resolution EU/RC64/R6: Investing in children: the European child and adolescent health strategy 2015-2020 and Investing in children: the European child maltreatment prevention action plan 2015-2020. Copenhagen: World Health Organization, Regional Office for Europe. 
World Health Organization. (2014b). Adverse Childhood Experiences Survey in Montenegro. Copenhagen: World Health Organization, Regional Office for Europe.

World Health Organization. (2014c). Global Status Report on Violence Prevention. Geneva: WHO.

\section{REFERENCES}

Belsky, J. (1980). Child maltreatment: An ecological integration. American Psychologist, 35, 320-335.

Butchart, A., Harvey, A. P., Mian, M., \& Furniss, T. (2006). Preventing child maltreatment: a guide to taking action and generating evidence. Geneva: World Health Organization and International Society for Prevention of Child Abuse and Neglect.

Bronfenbrenner, U. (1993). Ecological model of human development. International Encyclopedia of Education, 3.

Donnelly, M., \& Straus, M. A. (2005). Corporal punishment of children in theoretical perspective. New Haven, CT: Yale University Press.

Durrant, J., \& Ensom, R. (2012). Physical punishment of children: lessons from 20 years of research. Canadian Medical Association Journal, 184, (13), 73-1376.

Ferguson, C.J. (2013). Spanking, corporal punishment and negative long-term outcomes: A meta-analytic review of longitudinal studies. Clinical Psychology Review, 33, 196-208.

Gershoff, E.T. (2010). More harm than good: A summary of scientific research on the intended and unintended effects of corporal punishment on children. Law and Contemporary Problems. 73(2), 31-56.

Gershoff, E.T. (2013). Spanking and child development: We know enough now to stop hitting our children. Child Development Perspectives, 7 (3), 133-137. 
Global Initiative to End All Corporal Punishment of Children. (2014). Prohibiting all corporal punishment of children: progress and delay-Progress toward prohibiting all corporal punishment. Briefing prepared by the Global Initiative to End All Corporal Punishment of Children.

Government of Republic of Macedonia. Law on Child Protection (Official Gazette of the R.M., No. 23/13, 12/14, 44/14, 144/14, 10/15, 25/15, 150/15 ). Government of Republic of Macedonia.

Government of Republic of Macedonia. Family Law (Official Gazette of the R.M., No 80/1992, 9/1996, 38/2004, 33/2006, 84/2008, 67/10, 156/10, 39/12,44/12, 38/14,115/14, 104/15,150/15). Government of Republic of Macedonia.

Government of Republic of Macedonia. Law on Primary Education (Official Gazette of the R.M., No. 103/2008, 33/2010, 116/2010, 156/2010, 18/2011, 42/2011, 51/2011, 6/2012, 100/2012, 24/2013, 41/2014, 116/2014, 135/2014, 10/2015, 98/2015, 145/2015, 30/2016, 127/16 Government of Republic of Macedonia.

Government of Republic of Macedonia. Law on Secondary Education (Official Gazette of the R.M., No. 44/1995, 24/1996, 34/1996, 35/1997, 82/1999, 29/2002, 40/2003, 42/2003, 67/2004, 55/2005, 113/2005, 35/2006, 30/2007, 49/2007, 81/2008, 92/2008, 33/2010, 116/2010, 156/2010, 18/2011, 42/2011, 51/2011, 6/2012, 100/2012, 24/2013, 41/2014, 116/2014, 135/2014, 10/2015, 98/2015, 145/2015, 30/2016,127/2016). Government of Republic of Macedonia.

Government of Republic of Macedonia. Law on social protection (Official Gazette of the R.M., No. 79/09, 36/11, 51/11, 166/12, 15/13, 79/13, 164/13, 187/13, 38/14, 44/14, 116/14, 180/14, 33/15, 72/15, 104/15, 150/15, 173/15, 30/16). Government of Republic of Macedonia.

Government of Republic of Macedonia. Law on Health Care (Official Gazette of the R.M., No. 43/2012, 145/2012, 87/2013, 164/2013, 39/2014,4 3 / 2014 , 132/2014，188/2014, 10/2015). Government of Republic of Macedonia. 
Government of Republic of Macedonia. Law on Health Insurance (Official Gazette of the R.M., No. 25/2000, 96/2000, 50/2001, 11/2002, 31/2003, 84/2005, 37/2006, 18/2007, 36/2007, 82/2008, 98/2008, 6/2009, 67/2009, 50/2010, 156/2010, 53/2011,26/2012, 16/2013, 91/2013, 187/2013, 43/2014, 44/2014, 97/2014, 112/2014,113/2014). Government of Republic of Macedonia.

Gray J., Jordanova Pesevska, D., Sethi, D., Ramiro González, M.D. \& Yon Y. (2016). Handbook on developing national action plans to prevent child maltreatment. Copenhagen: World Health Organization.

Health Insurance Fund of Macedonia. fzo.org.mk, 2016, Retrieved from http:// www.fzo.org.mk/default.asp?ItemID=6C8BDADE268D2D489302275C6FF8 F2E.

Jordanova Peshevska, D., Tozija, F., Jordanova, T., Vaskova, P., \& Vaskova I. (2016). Implementing Sustainable Development Goals by Preventing Child Abuse and Neglect. Eurodialogue, 22, 291-304.

Kempe, C.H., Silverman F.N., Steele, B.F., Droegemueller, W., \& Silver, H.J. (1962). The battered-child syndrome. JAMA, 7 (181), 17-24.

Krug, E.G., Dahlberg, L.L., Mercy, J.A., Zwi, A.B., \& Lozano, R. (2002).World report on violence and health. Geneva: World Health Organization.

Ministry of Labor and Social Policy of Republic of Macedonia. (2010). National Strategy forthe Fight against Poverty and Social Exclusion, 2010-2020. Skopje: Ministry of Labor and Social Policy of Republic of Macedonia.

Ministry of Health, Ministry of Education and Science, and Ministry of Labor and Social Policy (2012a). Republic of Macedonia Multiple Indicator Cluster Survey, 2011. Skopje: Ministry of Health, Ministry of Education and Science, and Ministry of Labor and Social Policy.

Ministry of Labor and Social Policy of Republic of Macedonia. (2012b). National Plan of Action on the Rights of the Child (2012-2015). Skopje: Ministry of Labor and Social Policy of Republic of Macedonia. 
Ministry of Labor and Social Policy and Ministry of Health of Republic of Macedonia. (2013a). National Action Plan for Prevention and Combating Child Abuse and Neglect (2013-2015). Skopje: Ministry of Labor and Social Policy and Ministry of Health of Republic of Macedonia.

Ministry of Labor and Social Policy of Republic of Macedonia. (2013b). National Strategy for prevention and protection domestic violence (2012-2015). Skopje: Ministry of Labor and Social Policy of Republic of Macedonia.

Ministry of Labor and Social Policy of Republic of Macedonia. (2013c). Action Plan for Prevention and Combatting Sexual Abuse of Children and Pedophilia (2009-2012). Skopje: Ministry of Labor and Social Policy of Republic of Macedonia.

Ministry of Labor and Social Policy of Republic of Macedonia. (2013d). Action Plan for Children on the Streets 2013-2015. Ministry of Labor and Social Policy of Republic of Macedonia.

Pinheiro, S.P. (2006). World report on violence against children. Geneva: United Nations United Nations Secretary-General's Study on Violence against Children. Paunovic, M., Markovic, M., Vojvodic, K., Neskovic, A., Sethi, D., \& Grbic M. (2015). Survey of adverse childhood experiences among Serbian university students. Copenhagen: World Health Organization, Regional Office for Europe.

Qirjako, G., Burazeri, G., Sethi, D., \& Miho V. (2013). Community survey on prevalence of adverse childhood experiences in Albania. Copenhagen: World Health Organization.

Raleva, M., Jordanova Peshevska, D., Sethi, D. (2013). Survey of Adverse Childhood Experiences among Young People in the former Yugoslav Republic of Macedonia. Copenhagen: World Health Organization, Regional Office for Europe.

Sethi, D., Bellis, M., Hughes, K., Gilbert, R., Mitis, F., \& Galea, G. (2013). European report on preventing child maltreatment. Copenhagen: World Health Organization, Regional Office for Europe. 
Sethi, D., \& Jordanova Peshevska, D. (2014). Preventing Interpersonal Violence in Europe. Macedonian Journal for Medical Sciences, 7, 346-348. doi.org/10.3889/ MJMS.1857.5773.2014.0419.

Tozija, F., Gjorgjev, D., Kjosevska, E., \& Kendrovski, V. (2008). 2007/2008 Global School Based Student Health Results, Republic of Macedonia. Skopje: Republic Institute for Health Protection.

Tozija, F., Jordanova Peshevska, D., (2016). Translating Knowledge into Violence Prevention Policy towards the Sustainable Development Goals in the Republic of Macedonia. Eurodialogue, 22, 262-282.

UNICEF. (2010). Child Disciplinary Practices at Home: Evidence from a Range of Low- and Middle Income Countries. New York: UNICEF.

UNICEF. (2014). UNICEF Annual Report 2014 Former Yugoslav Republic of Macedonia. Skopje: UNICEF.

United Nations General Assembly, Convention on the Rights of the Child, 1989, Retrieved from: http://srsg.violenceagainstchildren.org/sites/default/files/ documents/docs/A RES-44-25_EN.pdf

World Health Organization. (1999). Social Change and Mental Health, Violence and Injury

Prevention. Report of the Consultation on Child Abuse Prevention, 29-31 March 1999. Geneva: WHO.

World Health Organization Assembly Resolution WHA56.24 (2003). Retrieved from http://www.who.int/features/2003/05b/en/

World Health Organization (2005). WHO Regional Committee for Europe resolution EUR/RC55/R9 on prevention of injuries in the WHO European Region. Copenhagen: WHO Regional Office for Europe. Retrieved from http://www. euro.who.int/_data/assets/pdf_file/0017/88100/RC55_eres09.pdf

World Health Organization. (2012). European Health 2020: a European policy framework supporting action across government and society for health and well-being. Copenhagen: World Health Organization, Regional Office for Europe. 
World Health Organization. (2013). Global health estimates - Disease and injury regional estimates 2000-2011 [on line data base]. Geneva: Author. Retrieved from http://www.who.int/healthinfo/global_burden_disease/en/

World Health Organization. (2014a). WHO Regional Committee for Europe resolution EU/RC64/R6: Investing in children: the European child and adolescent health strategy 2015-2020 and Investing in children: the European child maltreatment prevention action plan 2015-2020. Copenhagen: World Health Organization, Regional Office for Europe.

World Health Organization. (2014b). Adverse Childhood Experiences Survey in Montenegro. Copenhagen: World Health Organization, Regional Office for Europe.

World Health Organization. (2014c). Global Status Report on Violence Prevention. Geneva: WHO. 
